\title{
Assessment of foot health and animal welfare: clinical findings in 229 dairy Mediterranean Buffaloes (Bubalus bubalis) affected by foot disorders
}

Jacopo Guccione ${ }^{1}$, Christian Carcasole ${ }^{2}$, Maher Alsaaod $^{3}$, Luigi D’Andrea', Antonio Di Loria ${ }^{4}$, Angela De Rosa ${ }^{1}$, Paolo Ciaramella ${ }^{1 *}$ (D) and Adrian Steiner ${ }^{3}$

\begin{abstract}
Background: Lameness represents the third most important health-related cause of economic loss in the dairy industry after fertility and mastitis. Although, dairy Mediterranean Buffaloes (MB) and dairy cows share similar breeding systems predisposing to similar herd problems, published studies exploring its relevance and role in these ruminants are still rare and incomplete. The aims of this study were to describe the clinical findings of foot disorders (FDs) in dairy MB and their influence on animal welfare, determined by assessment of locomotion score (LS), body condition score (BCS) and cleanliness score (CS).

Results: Of 1297 multiparous MB submitted to routine trimming procedures, 229 buffaloes showed at least one FD. The prevalence of buffaloes affected by FDs was $17.7 \%$, while motility and lameness indexes were $84.1 \%$ (1091/1297) and $15.9 \%$ (206/1297), respectively. Overgrowth was present in $17.0 \%$ (220/1297), corkscrew claw in $15.8 \%$ (205/1297), interdigital phlegmon in $0.9 \%$ (12/1297), white line abscess in $0.8 \%$ (11/1297), digital dermatitis in $0.1 \%(1 / 1297)$ and interdigital hyperplasia in $0.1 \%$ (1/1297). Simultaneous presence of FDs was recorded in 17. $0 \%$ of MB (221/1297): overgrowth and corkscrew claw occurred together in $15.8 \%$ of cases (205/1297), overgrowth and interdigital phlegmon in $0.3 \%$ (4/1297), overgrowth and white line abscess in $0.8 \%$ (11/1297), digital dermatitis and interdigital hyperplasia in $0.1 \%$ (1/1297). The presence of FDs was always associated with lameness $(L S>2)$, except from $23 \mathrm{MB}$ with simultaneous overgrowth and interdigital phlegmon occurrence. The majority of MB within the under-conditioned group $(95.5 \%, 43 / 45)$ and all those with CS > $2(122 / 122)$ had a locomotion score above the threshold of normality ( $L S>2$ ). Furthermore, foot diseases such as interdigital hyperplasia, white line abscess and digital dermatitis or interdigital hyperplasia seemed to occur more frequently associated with decreased BCS and increased CS scores.
\end{abstract}

Conclusions: This study describes for the first time the involvement of white line disease, interdigital phlegmona, digital dermatitis and interdigital hyperplasia in foot disorders of dairy Mediterranean buffalo and shows their association with an impairment of animal welfare.

Keywords: Foot disorders, Claw, Welfare, Lameness, Mediterranean Buffalo, Corkscrew claw, White line disease, Interdigital phlegmona, Digital dermatitis, Interdigital hyperplasia

\footnotetext{
* Correspondence: paociara@unina.it

'Department of Veterinary Medicine and Animal Productions, University of

Napoli "Federico II", Via F. Delpino 1, 80137 Naples, Italy

Full list of author information is available at the end of the article
} 


\section{Background}

Foot health has been classified as the most important welfare problem in dairy cows, and its surveillance is the most representative animal-based indicator of welfare in dairy cattle $[1,2]$. Additionally, lameness due to foot disorders represents the third most important healthrelated cause of economic loss in dairy industry after reproduction disorders and mastitis [3]. The financial loss can be measured in terms of decreased milk yield [4], reduced reproductive performance [5], increased culling rate, and increased production costs [4].

In Europe, the number of Mediterranean Buffaloes (MB) bred is $\sim 450.000$ animals, of which $\sim 84 \%$ is from Italy [6]. Although, these ruminants and dairy cows share similar breeding systems predisposing to similar herd problems [7], only reproductive disorders [8] and mastitis $[9,10]$ have been recognized as cause of important economic loss in MB so far. Foot diseases were always considered virtually non-existent in MB herds [11]; as a consequence, only a few and incomplete studies exploring the role and economic relevance of foot disorders (FDs) in this dairy population have been performed [11, 12].

As widely known in cows, FDs impair animal welfare and some of the most important are associated with lameness [13], reduction in body condition score (BCS) [14], and impairment of cleanliness score (CS) [15]. Indeed in herd with high percentage of FDs, lameness and behavioral changes (e.g. reduced total eating time, meals per day, increased lie down time, etc.) of the affected animals are often observed [16, 17], as a consequence of discomfort and a painful status [18-20]. As in cows, a Welfare Quality ${ }^{\circ}$ [21] system (www.welfarequality.net) was developed also for Mediterranean buffaloes; lameness, BCS and CS are some of the criteria and measures for welfare assessment introduced by this project [22, 23].

The most common FDs in dairy cows comprise: sole ulcers (SU), white line disease (WLD), digital dermatitis (DD) and interdigital necrobacillosis (interdigital phlegmon - IP) [24, 25], while in MB, claw overgrowth (OG) and formation of corkscrew claws (CC) are the only claw disorders described until now [26]; no data are available about other type of FDs causing lameness.

In the field, the diagnosis of FDs can sometimes be challenging, because not all lesions cause lameness, and animals often have more than one type of lesion per foot; SU and IP, when present, are likely to be the cause of lameness while WLD, DD and heel horn erosion can frequently be present in non-lame cows [13]. In these animals a remarkable clinical support could be provided by novel electronic sensor systems able to automatically detect lameness due to foot lesions, actually not available for MB [27-29]. Considering these premises, the aim of this study was to describe the clinical findings of foot disorders (FDs) observed during routine foot trimming in dairy $\mathrm{MB}$ and their influence on animal welfare.

\section{Methods \\ Animals and farms}

The survey was performed on 1297 MB from 4 free-stall dairy farms in the Latina District - Middle Italy. This samples size was calculated by using the formula proposed by Thrusfield [30] considering the following values: study population (378.000 MB head in 2015) [31], expected prevalence of FDs (39.5\% in multiparous cows) [32], confidence interval $95 \%$ and desired absolute precision (5\%).

Farms were selected following convenient sampling by the local veterinary practicing claw-trimmer. All of them were characterized by barns with solid grooved concrete floors in the walking and feeding alleys. The lying area consisted either of elevated cubicles covered with rubber mattresses for milking $\mathrm{MB}$ or of a roofed deep straw yard area for dry MB. In the farms enrolled, similar cleaning procedures were employed. All the animals enrolled were fed with a total mixed ratio including hay, silage and a multi-vitamin integrator. In all farms, milking animals were fed and milked two times/day. All the enrolled farms were characterized by a spring-summer deseasonalized calving system.

\section{Data acquisition}

All the procedures performed in this study followed the common good clinical practices and received an institutional approval by Ethical Animal Care and Use Committee of University of Naples "Federico II"; moreover the farmers were previously informed and in agreement with purpose and methods used. Dairy farms were visited between April 2014 and March 2015. Routine foot trimming procedures were performed on all multiparous buffalo cows ( $\geq 2$ lactations), whether lame or not, by the same investigator, one-time per year.

\section{Foot disorders}

Presence or absence of FDs, as well as their localization, were recorded at claw trimming. The lesions observed in buffalo cows were categorized according to the ICAR Claw Health Atlas for cows [33], because of the lack of previous studies describing FDs in buffaloes.

Similar to the definition in cows [34], claw overgrowth (hereafter referred to as "overgrowth" [OG]) in MB was considered as an excessive elongation of the claws. No studies describing claws' anatomical differences between $\mathrm{MB}$ and cows were published so far. According to the experience of the authors, the normal dorsal wall length (distance from coronet to tip of claw) in MB (after the foot-trimming) is usually considered $9 \mathrm{~cm}$. As a 
consequence, lengths ranging from $\geq 9.1$ to $\leq 10 \mathrm{~cm}$ were considered as moderate OG, but still within an acceptable range; a dorsal wall length exceeding $10 \mathrm{~cm}$ was instead considered affected by severe OG and categorized as FD by the authors in the current study.

Regarding CC, as for cows, it was considered as any torsion of either the outer or inner claw characterized by presence of the dorsal edge of the wall deviating from a straight line [33]. Corkscrew claw was diagnosed, if complete correction of the torsion at claw trimming was not possible.

\section{Animal welfare}

All the animals affected by FDs were submitted to a complete clinical examination and their welfare status was determined by assessment of locomotion score (LS), body condition score (BCS) and cleanliness score (CS).

\section{Locomotion score}

The LS of each animal was assessed and recorded before trimming by one and the same investigator to avoid inter-observer differences in scoring. Observations were performed from the side and the rear of the buffalo cow, while it was moved to the trimming chute on flat and non-slippery surfaces. Buffalo cows were evaluated for their lameness status using the 5-point LS system described by Sprecher et al. [35] based on observation of posture and gait. The score was also dichotomized in a group with lameness status "non-lame" (scores 1-2) and a group with lameness status "lame" (scores 3-5) for the statistical analysis. A mobility score system validated for cows was used in the present study due to the lack of a classification system specific for MB. A LS $>2$ was considered indicative of impairment of welfare.

\section{Body condition score}

All the scorings were performed by one and the same investigator when the animals affected by FDs were confined in the trimming chute. The BCS was estimated by visual inspection of the animals, and manual palpation of four areas of the body where MB store fat: ribs, spine, hips and base of the tail (hereafter referred to as "tail") according to a 5-point scoring method introduced by [36] and slightly modified by the authors (Table 1). A score within the range of 1 (emaciated) and 5 (obese), with increments of 0.25 was given to each animal enrolled (score $3=$ ideal BCS). For the analysis, BCS was grouped as under-conditioned $(\mathrm{BCS} \leq 2.50)$, normally conditioned $(\mathrm{BCS} \geq 2.75$ and $\leq 3.50)$, and overconditioned $(\mathrm{BCS} \geq 3.75)$. Impairment of welfare was considered in animals that were under or overconditioned ( $\mathrm{BCS} \leq 2.5$ or $\geq 3.75$, respectively).

\section{Cleanliness score}

Cleanliness score was assessed using a scoring method previously reported by Nielsen et al. [15] for cows. Briefly, hind feet and limbs were the anatomical area evaluated always by the same investigator before foottrimming. The scoring system aimed to track the amount of manure present and the distance it extended proximally up the leg by means of an ordinal scale from 1 to 4 , in which: $1=$ little or no manure above the coronary band; $2=$ minor splashing above the coronary band; 3 = distinct plaques of manure above the coronary band, but with hair coat visible; $4=$ solid plaques of manure extending high up to the hock and stifle. To the knowledge of the authors, no studies describing the effects of $\mathrm{CS}$ on MB welfare were published so far; as a consequence, according to the experience of the authors, values of $\mathrm{CS}>2$ were considered indicative of impairment of welfare.

Table 1 Description of assessment criteria for individual components of the BCS in Mediterranean buffaloes (ribs, spine, hips, and tail) according to Ezenwa et al. [36] modified

\begin{tabular}{|c|c|c|c|c|}
\hline \multicolumn{5}{|c|}{ Region of body } \\
\hline Score & Ribs & Spine & Hips & Tail \\
\hline $\begin{array}{l}5 \\
\text { (Obese) }\end{array}$ & $\begin{array}{l}\text { Not visible; fatty layer on and } \\
\text { between ribs }\end{array}$ & $\begin{array}{l}\text { Spine bones not visible. Spine sits in } \\
\text { slight depression between fatty bulges } \\
\text { left and right of spine }\end{array}$ & $\begin{array}{l}\text { Convex, smooth rear, hip } \\
\text { bones not visually apparent }\end{array}$ & $\begin{array}{l}\text { Tail base sits in depression } \\
\text { surrounded by soft fatty } \\
\text { tissue }\end{array}$ \\
\hline 4 & $\begin{array}{l}\text { Few ribs visible towards } \\
\text { abdomen; ribs can be felt }\end{array}$ & $\begin{array}{l}\text { Spine bones not visible. Spine feels flat; } \\
\text { bone and surrounding tissue are on level }\end{array}$ & $\begin{array}{l}\text { Hip bones can be seen, } \\
\text { round smooth appearance } \\
\text { and feel }\end{array}$ & $\begin{array}{l}\text { Tail base on level with } \\
\text { surrounding fatty tissue }\end{array}$ \\
\hline $\begin{array}{l}3 \\
\text { (ldeal) }\end{array}$ & $\begin{array}{l}\text { Some ribs visible in center of } \\
\text { ribcage; abdominal ribs feel } \\
\text { ridged }\end{array}$ & $\begin{array}{l}\text { Spine palpable as a slightly elevated } \\
\text { bone center-line }\end{array}$ & $\begin{array}{l}\text { Points of hips distinctly } \\
\text { visible; bone easy to feel but } \\
\text { not protruding }\end{array}$ & $\begin{array}{l}\text { Tail base protrudes slightly; } \\
\text { obvious by touch, but not } \\
\text { by sight }\end{array}$ \\
\hline 2 & $\begin{array}{l}\text { Ribs visible throughout; all } \\
\text { have ridged feel }\end{array}$ & $\begin{array}{l}\text { Individual spinal vertebrae clearly } \\
\text { palpable }\end{array}$ & $\begin{array}{l}\text { Points of hips protrude; } \\
\text { flanks are concave }\end{array}$ & $\begin{array}{l}\text { Tail base visibly sticks up } \\
\text { from surrounding tissue }\end{array}$ \\
\hline 1 & $\begin{array}{l}\text { Ribs clearly visible with deep } \\
\text { depressions between them; } \\
\text { very ridged feel }\end{array}$ & $\begin{array}{l}\text { Vertebrae distinguishable by sight and } \\
\text { touch }\end{array}$ & $\begin{array}{l}\text { Hip bones protrude beyond } \\
\text { the hip point; emaciated } \\
\text { rear }\end{array}$ & $\begin{array}{l}\text { Tissue surrounding tail base } \\
\text { forms round hollow defined } \\
\text { by pelvis }\end{array}$ \\
\hline
\end{tabular}


Data regarding type of FDs, LS, BCS and CS were recorded on a spreadsheet and stored before the end of the foot trimming procedure, using the ear tag number of each buffalo cow to unequivocally identify individual animals. Information regarding farm management (type of feeding system, birth seasonality, type of barn, number of milking/day) as well as productive status of the animals with FD (milking or dried-off $\mathrm{MB}$ ) were obtained from the farmers using a standardized questionnaire.

\section{Statistical analysis}

All parameters were analyzed by standard descriptive statistics, and data distribution was assessed using histograms, normal probability plots and Shapiro Wilk tests. Data were expressed as absolute numbers, percentages and averages. Prevalences (PR), motility and lameness indexes ( $\mathrm{MI}$ and $\mathrm{LI}$, respectively) were also calculated. $\mathrm{PR}=$ $\mathrm{E}_{+} /\left(\mathrm{E}_{+}+\mathrm{E}_{-}\right)$, where $\mathrm{E}_{+}$represents the number of animals showing the "Event" studied, while $\mathrm{E}_{-}$represents the number of animals without the Event but that can express it (animals at risk); $\mathrm{MI}=$ number of cows not lame/number of multiparous cows in the herd; LI = number of cows lame/number of multiparous cows in herd [37]. Significant differences between expected and observed frequencies of categorical data (type of FD, LS, BCS, CS and productive status) were assessed by means of contingency tables, using $X^{2}$-test. Probabilities of $P<0.05$ were considered significant. Data were analyzed using dedicated software (SPSS, Version 17.0, Chicago, IL).

\section{Results}

\section{Prevalence of foot disorders}

The prevalence of animals affected by FDs was $17.7 \%$ (229/1297): overgrowth (OG) was present in $17.0 \%$ (220/1297) of the MB enrolled, corkscrew claw (CC) in $15.8 \%(205 / 1297)$, interdigital phlegmon (IP) in $0.9 \%$ (12/1297), white line abscess (WLA) in $0.8 \%$ (11/1297), digital dermatitis (DD) in $0.1 \%(1 / 1297)$ and interdigital hyperplasia $(\mathrm{IH})$ in $0.1 \%(1 / 1297)$. Considering the whole sampling population, simultaneous presence of FDs was recorded in $17.0 \%$ of MB (221/1297): OG + CC occurred together in $15.8 \%$ of cases $(205 / 1297)$, OG + IP in $0.3 \%(4 / 1297)$, OG + WLA in $0.8 \%(11 / 1297)$ and $\mathrm{DD}+\mathrm{IH}$ in $0.1 \%(1 / 1297)$. Significant associations between OG and CC $\left[\chi^{2}=1191.967\right.$, degree of freedom (df) $=1, P<0.0001]$ and between OG and WLA $\left(\chi^{2}=\right.$ 54.311, $\mathrm{df}=1, P<0.0001)$ were detected. No lameness caused by orthopedic pathology located outside the feet was detected during the investigation.

Prevalence, localizations and type of disorders in the population affected by FDs are indicated in Table 2 . Briefly, considering the group of $\mathrm{MB}$ affected by a FD, $26.2 \%(60 / 229)$ of FDs were located in the front limbs,
Table 2 Type, prevalence and localization of foot disorders recorded in Mediterranean buffaloes $(n=229)$

\begin{tabular}{llllll}
\hline FDs & Prevalence & Limb & Prevalence & Claw & Prevalence \\
\hline OG & $96.1 \%(220)$ & $\mathrm{FL}+\mathrm{HL}$ & $100 \%(220 / 220)$ & $/$ & $/$ \\
CC & $89.5 \%(205)$ & $\mathrm{FL}$ & $27.8 \%(57 / 205)$ & $\mathrm{MC}$ & $100 \%(57 / 57)$ \\
& & & & $\mathrm{LC}$ & $/$ \\
& & $\mathrm{HL}$ & $72.2 \%(148 / 205)$ & $\mathrm{MC}$ & $93.9 \%(139 / 148)$ \\
& & & & $\mathrm{LC}$ & $6.1 \%(9 / 148)$ \\
IP & $5.2 \%(12)$ & $\mathrm{FL}$ & $8.3 \%(1 / 12)$ & $/$ & $/$ \\
& & $\mathrm{HL}$ & $91.7 \%(11 / 12)$ & $/$ & $/$ \\
WLA & $4.8 \%(11)$ & $\mathrm{FL}$ & $27.3 \%(3 / 11)$ & $\mathrm{MC}$ & $100 \%(3 / 3)$ \\
& & $\mathrm{HL}$ & $72,7 \%(8 / 11)$ & $\mathrm{LC}$ & $100 \%(8 / 8)$ \\
$\mathrm{DD}$ & $0.4 \%(1)$ & $\mathrm{HL}$ & $100 \%(1 / 1)$ & $/$ & $/$ \\
IH & $0.4 \%(1)$ & $\mathrm{HL}$ & $100 \%(1 / 1)$ & $/$ & $/$
\end{tabular}

$(\mathrm{x})=$ number of buffaloes; FD foot disorder, OG overgrow, CC corkscrew, IP interdigital phlegmon, WLA white line abscess, DD digital dermatitis, IH interdigital hyperplasia, FL front limb, $H L$ hind limb, MC medial claw, LC lateral claw

while $73.8 \%(169 / 229)$ were located in the hind limbs, and $7.8 \%(16 / 205)$ both in front and hind limbs. Of all FDs identified, 216 (94.3\%) were non-infectious disorders and 13 (5.7\%) infectious disorders.

\section{Animal welfare}

Of all buffaloes affected by FDs, $90.0 \%$ (206/229) showed LS score $>2,19.6 \%(45 / 229)$ a $\mathrm{BCS} \leq 2.5$ and $59.8 \%(137 / 229)$ a $C S>2$.

\section{Lameness prevalence and locomotion score}

Motility and lameness indexes recorded in the overall sample population were $84.1 \%(1091 / 1297)$, and $15.9 \%$ (206/1297), respectively; $57.3 \%(118 / 206)$ of lame MB were milking while the $42.7 \%(88 / 206)$ were dried-off. considering all the animals enrolled, lameness was always associated with the presence of at least one FD $(\mathrm{LS}>2) \quad\left(\chi^{2}=1142.13, \mathrm{df}=1, \quad P<0.0001\right)$, except for $23 \mathrm{MB}$ with simultaneous occurrence of OG + CC. Significant differences between expected and observed frequencies of various LS on buffaloes affected by FDs were found for OG $\left(\chi^{2}=94.125, \mathrm{df}=3, P<0.0001\right), \mathrm{CC}\left(\chi^{2}=\right.$ 229.000, df $=3, P<0.0001)$, IP $\left(\chi^{2}=157.922, \mathrm{df}=3, P<\right.$ $0.0001)$ and WLA $\left(\chi^{2}=133.072, \quad \mathrm{df}=3, \quad P<0.0001\right)$. Prevalence, type of FDs and associated degree of lameness in the 229 buffaloes with FDs are described in detail in Table 3. Briefly, $10.0 \%(23 / 229)$ of MB were scored as LS2 (non-lame group), while $79.5 \%$ (182/229), $7.4 \%$ $(17 / 229)$ and $3.1 \%(7 / 229)$ as LS3, LS4 and LS5, respectively (lame group). No statistically significant difference was found between $\mathrm{MB}$ with different productive status (milking versus dried-off) concerning their lameness status (lame versus non-lame). 
Table 3 Type and prevalence of foot disorders in lame and non-lame Mediterranean buffaloes $(n=229)$ associated with different locomotion scores

\begin{tabular}{llllll}
\hline LS & OG + CC & OG + IP & OG +WLA & DD + IH & $\mathbb{I P}$ \\
\hline 2 & $10.0 \%(23)$ & - & - & - & - \\
3 & $79.5 \%(182)$ & - & - & - & - \\
4 & - & $1.7 \%(4)$ & $2.2 \%(5)$ & - & $3.5 \%(8)$ \\
5 & - & - & $2.6 \%(6)$ & $0.4 \%(1)$ & - \\
\hline
\end{tabular}

$(\mathrm{x})=$ number of buffaloes, $L S$ locomotion score, $F D$ foot disorder, $B C S$ body condition score, CS cleanliness score, OG overgrow, CC corkscrew, IP interdigital phlegmon, WLA white line abscess, $D D$ digital dermatitis, IH interdigital hyperplasia

\section{Body condition score}

Regarding the $\mathrm{BCS}$, none of the $\mathrm{MB}$ with FDs were overconditioned ( $\mathrm{BCS} \geq 3.75)$, while $80.3 \%(184 / 229)$ were normal-conditioned ( $\mathrm{BCS} \geq 2.75$ and $\leq 3.5$ ) and $19.7 \%$ $(45 / 229)$ were under-conditioned $(\mathrm{BCS} \leq 2.5)$. No statistically significant difference was found in MB with FDs between lameness status lame $(n=206)$ versus non-lame $(n=23)$ concerning BCS distribution. Of all MB with FDs, such with OG or CC were mainly associated with a BCS ranging between 2.50 and 3.00 while $\mathrm{MB}$ with WLA or IP mainly showed a BCS of 2.25 and 2.5 ; the only case of $\mathrm{DD}+\mathrm{IH}$ detected showed a BCS of 2.75. A significant association between BCS and OG $\left(\chi^{2}=\right.$ 33.408, $\mathrm{df}=3, P<0.0001)$ as well as between BCS and $\mathrm{CC}\left(\chi^{2}=123.877, \mathrm{df}=3, P<0.0001\right), \mathrm{BCS}$ and IP $\left(\chi^{2}=\right.$ 46.006, $\mathrm{df}=3, P<0.0001), \mathrm{BCS}$ and WLA $\left(\chi^{2}=206.966\right.$, df $=3, P<0.0001)$ were detected.

Prevalence and type of lesions in lame and non-lame $\mathrm{MB}$ enrolled affected by FDs, according to BCS observed, are reported in Table 4.

\section{Cleanliness score}

The CS 4 was recorded in $50.2 \%(115 / 229)$ of MB affected with FDs, while it was 3 in $9.6 \%(22 / 229), 2$ in $6.6 \%(15 / 229)$ and 1 in $33.6 \%(77 / 229)$, respectively. In the $\mathrm{MB}$ with FD (lame and non-lame), the CS ranged between 1 and 4. Overgrowth and CC were detected at any scoring point, WLA and IP mainly at scores 3 and 4, and the only case of $\mathrm{HH}+$ ID showed score 4. Significant associations were found between CS and CC $\left(\chi^{2}=\right.$ 15.335, $\mathrm{df}=3, P<0.01)$ as well as between CS and WLA $\left(\chi^{2}=7.824, \mathrm{df}=3, P<0.05\right)$. No associations were instead recorded for CS and OG $\left(\chi^{2}=7.135, \mathrm{df}=3, P=0.068\right)$, and CS and IP $\left(\chi^{2}=7.106, \mathrm{df}=3, P=0.069\right)$.

In Table 4, prevalence and types of lesions are given in lame and non-lame buffaloes enrolled, according to CS observed.

\section{Discussion}

In this study, the clinical findings of foot disorders (FDs) affecting animal welfare are outlined for the first time in
Table 4 Type and prevalence of foot disorders in lame and non-lame Mediterranean buffaloes associated with different body condition scores and cleanliness scores

\begin{tabular}{|c|c|c|c|c|}
\hline Groups & $\mathrm{BCS}$ & FD & Prevalence & LS \\
\hline \multirow{3}{*}{$\begin{array}{l}\text { Non-lame } \\
(23)\end{array}$} & 2.50 & $\mathrm{OG}+\mathrm{CC}$ & $8.7 \%$ (2) & 2 \\
\hline & 2.75 & $\mathrm{OG}+\mathrm{CC}$ & $65.2 \%(15)$ & \\
\hline & 3.00 & $\mathrm{OG}+\mathrm{CC}$ & $26.1 \%(6)$ & \\
\hline \multirow{11}{*}{$\begin{array}{l}\text { Lame } \\
(206)\end{array}$} & \multirow[t]{3}{*}{2.25} & $O G+\mathbb{P}$ & $0.5 \%(1)$ & 4 \\
\hline & & $O G+W L A$ & $2.4 \%(5)$ & \\
\hline & & $\mathrm{OG}+\mathrm{WLA}$ & $1.9 \%(4)$ & 5 \\
\hline & \multirow[t]{4}{*}{2.50} & $\mathrm{OG}+\mathrm{CC}$ & $10.2 \%(21)$ & 3 \\
\hline & & $\mathbb{I P}$ & $3.9 \%(8)$ & 4 \\
\hline & & $O G+\mathbb{P}$ & $1.0 \%(2)$ & \\
\hline & & $\mathrm{OG}+\mathrm{WLA}$ & $1.0 \%(2)$ & 5 \\
\hline & \multirow[t]{3}{*}{2.75} & $\mathrm{OG}+\mathrm{CC}$ & $75.7 \%$ (156) & 3 \\
\hline & & $O G+\mathbb{P}$ & $0.5 \%(1)$ & 4 \\
\hline & & $\mathrm{DD}+\mathrm{IH}$ & $0.5 \%(1)$ & 5 \\
\hline & 3.00 & $\mathrm{OG}+\mathrm{CC}$ & $2.4 \%(5)$ & 3 \\
\hline Group & CS & $\mathrm{FD}$ & Prevalence & LS \\
\hline \multirow{4}{*}{$\begin{array}{l}\text { Non-lame } \\
\text { (23) }\end{array}$} & 1 & $\mathrm{OG}+\mathrm{CC}$ & $30.4 \%$ (7) & 2 \\
\hline & 2 & $\mathrm{OG}+\mathrm{CC}$ & $4.3 \%(1)$ & \\
\hline & 3 & $\mathrm{OG}+\mathrm{CC}$ & 8.7 \% (2) & \\
\hline & 4 & $\mathrm{OG}+\mathrm{CC}$ & $56.5 \%(13)$ & \\
\hline \multirow{13}{*}{$\begin{array}{l}\text { Lame } \\
\text { (206) }\end{array}$} & 1 & $\mathrm{OG}+\mathrm{CC}$ & $34.0 \%(70)$ & 3 \\
\hline & \multirow[t]{2}{*}{2} & $\mathrm{OG}+\mathrm{CC}$ & $6.3 \%$ (13) & 3 \\
\hline & & $\mathbb{I P}$ & $0.4 \%(1)$ & 4 \\
\hline & \multirow[t]{4}{*}{3} & $\mathrm{OG}+\mathrm{CC}$ & $8.2 \%(17)$ & 3 \\
\hline & & $O G+\mathbb{P}$ & $0.5 \%(1)$ & 4 \\
\hline & & $\mathrm{OG}+\mathrm{WLA}$ & $0.5 \%(1)$ & \\
\hline & & $O G+W L A$ & $0.5 \%(1)$ & 5 \\
\hline & \multirow[t]{6}{*}{4} & $\mathrm{OG}+\mathrm{CC}$ & $40.0 \%(82)$ & 3 \\
\hline & & $O G+\mathbb{P}$ & $1.5 \%(3)$ & 4 \\
\hline & & IP & $3.4 \%(7)$ & \\
\hline & & $\mathrm{OG}+\mathrm{WLA}$ & $1.9 \%(4)$ & \\
\hline & & $\mathrm{OG}+\mathrm{WLA}$ & $2.4 \%(5)$ & 5 \\
\hline & & $\mathrm{DD}+\mathrm{IH}$ & $0.5 \%(1)$ & \\
\hline
\end{tabular}

$(\mathrm{x})$ = number of buffaloes, $L S$ locomotion score, $F D$ foot disorder, $B C S$ body condition score, CS cleanliness score, OG overgrow, CC corkscrew, IP interdigital phlegmon, WLA white line abscess, $D D$ digital dermatitis, $I H$ interdigital hyperplasia

Mediterranean Buffaloes. Some FDs reported were never observed before in these ruminants. As a consequence, a comparative analysis with cows was done; in this context, the sample size was reached using the prevalence data originating from similar studies in cows [32], and it was more than tripled to increase the data's reliability.

The overall lameness index detected in the $1297 \mathrm{MB}$ enrolled was $15.9 \%(206 / 1297)$; similar results were 
found in analogous studies performed in dairy cow farms in several European countries. Indeed in recent studies, the prevalence of lameness in dairy cows ranged from 14.8 to $19.0 \%$ [24, 38]. Farmers, farm staff as well as veterinary practitioners traditionally tended to underestimate lameness in $\mathrm{MB}$ for a long time. This may be due to the low level of expression of the signs of pain by $\mathrm{MB}$ on one hand, and the lack of serious investigations performed in this field on the other hand. As described for cows, farmers may also do not feel the real necessity to investigate the problem, since they became tolerant to the levels of lameness in their herd, because the situation was similar to that of other herds they know [39]. Furthermore, unlike mastitis and infertility, from the farmers' perspective, lameness does not overtly impact on farm economics, as lame animals continue to produce milk. So, for busy farmers to care for a lame animal is of low priority [39]. In the current study, the analysis did not reveal a significant difference of lameness prevalence according to the productive status; however it is necessary to highlight that the lack of more accurate data regarding the exact phase of lactation (e.g.: fresh $\mathrm{MB}$ or early-, mid-, or late-lactation animals) or dry-off (e.g.: dry or close-up MB) and milk yield may represent one of the restrictions of this study.

Foot disorders observed were mainly localized on the hind feet $(73.8 \%)$ and less frequently on the front feet (26.2\%), confirming similar results recently described by Somers and O'Grady [25] for dairy cows, where 11.8 and $89.6 \%$ of the cows showed lesions recorded on front and hind feet, respectively.

Claw overgrowth (OG) represented the most frequent FD found in this study $(96.1 \%-220 / 229)$. Size and shape of the claw at any one time is a balance between growth and wear rate; several factors such as age of the animals, high concentrate feeding, degree of exercise and surface characteristics of the paddock and the stall alleys significantly influence the horn growth [40]. As shown in Table 3, severe OG was always detected in association with foot diseases (CC, WLA and IP) and the most frequent combination observed was represented by OG + CC (205/229). As widely described for cows [34], claw OG predisposes for the occurrence of others FDs potentially causing lameness also in MB.

During the current investigation, claw corkscrew (CC) was the most common non-infectious foot disease recorded both in the lame (182/206) and nonlame (23/23) group of MB (Tables 2 and 3), and it was observed only associated with OG as reported also by Cammarano and Marino [26]. In MB such as in cows, $\mathrm{CC}$ has been mainly ascribed to genetic heritable disorders, transmitted by bulls carrying the defects which should basically be excluded from reproduction $[12,40]$.
Regarding the influences of these two FDs on lameness, our data suggest that both OG and CC, when not associated with other foot diseases, are responsible for a mild (L2) to moderate (L3) lameness $(P<0.0001)$ (Table 3); the result obtained is in contrast with Napolitano et al. [11], who indicated this clinical sign as virtually absent in the 3 buffalo farms examined. Nevertheless, the LS values observed did not significantly influence the other welfare parameters considered (BCS and CS, Table 4), showing that these two FDs may not substantially affect buffaloes' welfare.

Regarding the white line abscess (WLA), it represents a white line disorder mainly secondary to weakness of the white line, resulting, at the same time, in an abnormal horn production as a consequence of a laminitic insult (coriosis) [34]. White line disorders are considered some of the most important causes of severe lameness in cows [32]. While $4.8 \%$ of the MB with FDs showed signs of WLA (Table 2), the values observed were lower than those recently described for lame cows, where the prevalence of WLA ranged from 17.2 to $23.5 \%$ [25, 32].

In the present investigation, WLA was significantly associated with OG $(P<0.0001$, Table 3$)$; in agreement with Blowey [40], also in MB claw overgrowth could be considered as predisposing factor for white line disorders, increasing significantly the weakness of the hoof. Furthermore, as reported by Barker et al. [41] in cows, several factors can significantly increase the risk of WLA occurrence such as herd size, access to pasture and solid grooved concrete floors; in particular shallow grooves or loss of friction of solid grooved concrete over time lead to slippery floor surfaces associated with an increase in lameness, alterations in gait and increasing pressure on the sole and white line [42]. Solid grooved concrete floors were present in the alleys of all the farms enrolled and may have contributed to the appearance of the FDs, although this hypothesis lacks further scientific evidence. As proven by Whay et al. [19], white line disorders can also reduce cow's nociceptive threshold increasing the sensitivity to pain. As shown in Tables 3 and 4, WLA was always associated with severe clinical lameness, suggesting that the pathology is painful also in MB $(P<0.0001, \mathrm{LS} \geq 4)$. As a consequence, the stressful condition experienced by the $\mathrm{MB}$ affected by WLA seemed to significantly influence the other welfare parameters considered: all of the animals were indeed in the under-conditioned group $(\mathrm{BCS} \leq 2.5-11 / 11$; Table 4$)$ and showed values of cleanliness score above the threshold (CS3: 2/11-CS4: 9/11; Table 4). Similarly to severely lame cows, the authors suppose that, also in MB, this impairment of welfare might mainly be the consequence of less active animals, reduced total eating time, numbers of meals per day or dry matter intake as well as a longer lying time $[16,43]$; further studies are necessary to confirm this hypothesis. 
Interdigital phlegmon (IP) represents the second most frequent foot infectious disease observed in the group of lame MB (5.2\%, Table 2); a similar prevalence (4.4\%) was described by DeFrain et al. [32] in cattle. Injuries of the interdigital skin are usually a prerequisite for the infection; stones, stubble, kale stems, hardened dung in the interdigital area, sticks, very dry pasture, or rough flooring can easily damage the area of the feet involved $[34,40]$. A bacterial invasion of the skin of the interdigital cleft mainly due to Fusobacterium necrophorum is usually associated with IP in cattle [39]. Unfortunately, no information regarding the injuries promoting the infection and the type of microorganisms primarily involved in MB' IP are available, representing another restriction of the study.

As described by Whay et al. [18, 19], lesions of the interdigital skin are often related to hyperalgesia and consequently to lameness. This seems to hold true also in $\mathrm{MB}$, because all the animals affected by IP had a severe lameness with gaits showing hesitating steps $(P<$ 0.0001) (LS4, Table 3). Moreover, considering the effects on BCS and CS, $91.7 \%(11 / 12)$ were in the underconditioned group $(\mathrm{BCS} \leq 2.75, P<0.0001)$ and rated with CS > 2 (CS3: 1/11-CS4: 10/11, $P=0.068$, Table 4). These results showed a lower effect of IP on impairment of behavior and welfare of affected animals than WLA.

Regarding digital dermatitis (DD), a single case of a DD-associated interdigital hyperplasia $(\mathrm{IH})$ was detected in the present study. Digital dermatitis is known as bacterial skin infection primarily affecting the epidermis and seriously compromising the welfare and productivity of affected cattle [44]. It was described for the first time in Italy by Cheli and Mortellaro [45] and since then, it rapidly spread all over the world. The DD lesion occurred on the tip of $\mathrm{IH}$ and was diagnosed according to the clinical picture, showing close similarity to that in dairy cattle. Neither histological evaluation nor PCR for the relevant Treponema species were performed. In comparison to the situation in dairy cattle [24, 25, 32], the prevalence of $\mathrm{DD}$ was very low in $\mathrm{MB}$, although management of both dairy species is very similar. The lack of a previous description in MB could be both related to the inability to recognize DD (if associated with a low LS) as well as to a lower sensitivity of this species to slurry exposure, commonly considered a major risk factor of DD in dairy cows [46]. This clinical findings merit further scientific attention.

As last, it is interesting to underline that other noninfectious foot diseases, such as sole ulcers (SU), were not found although they occur frequently in dairy cows. The pathogenesis of SU in dairy cow was recognized as the consequence of abnormal compression of the corium and nutritional imbalances, leading to ischemic necrosis, altered horn formation and formation of horn of poor quality, finally reaching the bearing surface of the sole [40]. The reason for the obvious difference in the prevalence of SU between MB and dairy cows is not known.

Making an overall judgement on the effect of FDs on welfare, as described for cows by Tadich et al. [13], a significant association between the presence of FDs and various degrees of lameness has been detected also in $\mathrm{MB}(P<0.0001)$. The majority of $\mathrm{MB}$ within the underconditioned group $(95.5 \%, 43 / 45)$ and all those with CS $>2(122 / 122)$ had a locomotion score above the threshold of normality (LS $>2$ ), adversely affecting buffaloes' welfare. Furthermore, foot diseases such as IP, WLA and DD or IH but not CC and OG seemed to occur more frequently associated with decreased BCS and increased CS scores (Table 4).

\section{Conclusions}

This study represents the first clinical description of involvement of white line disease, interdigital phlegmona, digital dermatitis and interdigital hyperplasia in foot disorders of dairy Mediterranean buffalo, revealing impairment of animal welfare of affected animals. More complete studies including the assessment of the pathogenesis, risk factors and economic impact of FDs on $\mathrm{MB}$ dairy industry are warranted. By improving the scientific knowledge concerning FDs of $\mathrm{MB}$, awareness of the problem and empathy with the welfare of these dairy ruminants can be increased.

\section{Abbreviations}

BCS, body condition score; CC, corkscrew; CS, cleanliness score; DD, digital

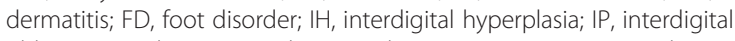
phlegmon; LI, lameness indexes; LS, locomotion score; MB, Mediterranean buffaloes; MI, motility index; OG, overgrow; PR, prevalence; WLA, white line abscess

\section{Acknowledgements}

The Authors acknowledge the precious collaboration of all the farmers involved during the study.

Funding

No funding was obtained for this study.

Availability of data and materials

All the data supporting the findings of the present study are included within the manuscript.

Authors' contributions

$J G, C C, P C \& A S$ participated in the conceptual aspect and design of the study. JG, CC, LDA, ADL, ADR \& AS involved in data collection. JG, MA, PC \& AS statistical evaluation and data interpretation. All authors provided consultation and coordination. JG, PC \& AS wrote the first draft of the manuscript, with all authors involved in reviewing. All authors read and approved the final version of the manuscript.

\section{Competing interests}

The authors declare that they have no competing interests.

Consent for publication

Not applicable. 


\section{Ethics approval and consent to participate}

The study received the institutional approval by the Ethical Animal Care and Use Committee of University of Studies of Naples "Federico II"(n.2016/ 0052962), moreover all the farmers involved was previously informed and in agreement about purposes and methods of the present investigation.

\section{Author details}

'Department of Veterinary Medicine and Animal Productions, University of Napoli "Federico II", Via F. Delpino 1, 80137 Naples, Italy. ${ }^{2}$ Veterinary practitioner, Latina District 04100, Italy. ${ }^{3}$ Clinic for Ruminants, Department of Clinical Veterinary Medicine, Vetsuisse-Faculty, University of Berne, 3012 Bern, Switzerland. ${ }^{4}$ Department of Health Science, University of Magna Graecia of Catanzaro, 88100 Catanzaro, Italy.

\section{Received: 10 March 2016 Accepted: 6 June 2016} Published online: 14 June 2016

\section{References}

1. Whay HR, Main DC, Green LE, Webster AJ. Assessment of the welfare of dairy cattle using animal-based measurements: direct observations and investigation of farm records. Vet Rec. 2003;153:197-202.

2. European Food Safety Authority. Scientific report of EFSA prepared by the animal health and animal welfare unit on the effects of farming systems on dairy cow welfare and disease. Annex EFSA J. 2009;1143:1-38.

3. Booth CJ, Warnick LD, Grohn YT, Maizon DO, Guard CL, Janssen D. Effect of lameness on culling in dairy cows. J Dairy Sci. 2004:87:4115-22.

4. Green LE, Hedges VJ, Schukken YH, Blowey RW, Packington AJ. The impact of clinical lameness on the milk yield of dairy cows. J Dairy Sci. 2002;85: 2250-56.

5. Garbarino EJ, Hernandez JA, Shearer JK, Risco CA, Thatcher WW. Effect of lameness on ovarian activity in postpartum Holstein cows. J Dairy Sci. 2004; 87:4123-31.

6. Vidu L, Diaconescu C, Udroiu A, Bacila V, Popa D, Popa R, Stanciu M. The buffalo -part of animal biodiversity in Romania and the importance for the bioeconomy. In 14th international multidisciplinary scientific geoconference surveying geology and mining ecology management. SGEM. 2014;5:665-72.

7. Guccione J, Cosandey A, Pesce A, Di Loria A, Pascale M, Piantedosi D, et al. Clinical outcomes and molecular genotyping of Staphylococcus aureus isolated from milk samples of dairyprimiparous Mediterranean buffaloes (Bubalus bubalis). J Dairy Sci. 2014;97:7606-13.

8. Vecchio D, Neglia G, Di Palo R, Prandi A, Gasparrini B, Balestrieri A, et al. Is a delayed treatment with $\mathrm{GnRH}$, hCG or progesterone beneficial for reducing embryonic mortality in buffaloes? Reprod Domest Anim. 2008;45:614-8.

9. Guccione J, Pesce A, Pascale M, Tommasini N, Garofalo F, Di Loria A, et al. Short communication: effects of systemic treatment with penethamate hydriodide on udder health and milk yields in dry primiparous Mediterranean buffaloes (Bubalus bubalis). J Dairy Sci. 2014;97:2219-25.

10. Guccione J, Perreten V, Steiner A, Thomann A, Pesce A, Ciaramella P, et al. Short communication: role of Streptococcus pluranimalium in Mediterranean buffaloes (Bubalus bubalis) with different udder health statuses. J Dairy Sci. 2016;99:2945-9.

11. Napolitano F, Grasso F, Bordi A, Tripaldi C, Saltalamacchia F, Pacelli C, et al. On-farm welfare assessment in dairy cattle and buffaloes: evaluation of some animal-based parameters. Ital J Anim Sci. 2005;4:223-31.

12. De Rosa G, Napolitano F, Grasso F, Pacelli C, Bordi A. On the development of a monitoring scheme of buffalo welfare at farm level. Ital J Anim Sci. 2005;4:115-25

13. Tadich N, Flor E, Green LE. Associations between hoof lesions and locomotion score in 1098 unsound dairy cows. Vet J. 2010;184:60-5.

14. Bicalho RC, Machado VS, Caixeta LS. Lameness in dairy cattle: a debilitating disease or a disease of debilitated cattle? A cross-sectional study of lameness prevalence and thickness of the digital cushion. J Dairy Sci. 2009; 92:3175-84.

15. Nielsen BH, Thomsen PT, Sørensen JT. Identifying risk factors for poor hind limb cleanliness in Danish loose-housed dairy cows. Anim. 2011;5:1613-19.

16. O'Callaghan KA, Cripps PJ, Downham DY, Murray RD. Subjective and objective assessment of pain and discomfort due to lameness in dairy cattle. Anim Welf. 2003;12:605-10

17. Flower FC, Sedbauer M, Carter E, Von Keyserlingk MAG, Sanderson DJ, Weary DM. Analgesics improve the gait of lame dairy cows. J Dairy Sci. 2008;91:3010-14
18. Whay HR, Waterman AE, Webster AJF. Associations between locomotion, claw lesion and nociceptive threshold in dairy heifers during the peripartum period. Vet J. 1997;154:155-61.

19. Whay HR, Waterman AE, Webster AJF, O'Brien JK. The influence of lesion type on the duration of hyperalgesia associated with hind limb lameness in dairy cattle. Vet J. 1998;156:23-9.

20. Belge F, Bildik A, Belge A, Kikcalp D, Atasoy N. Possible association between chronic laminitis and some biochemical parameters in dairy cattle. Aust Vet J. 2004:82:556-57.

21. Welfare Quality ${ }^{\circledast}$. Welfare quality assessment protocol for cattle. Lelystad: Welfare Quality Consortium; 2009.

22. De Rosa G, Napolitano F, Grasso F, Bilancione A, Spadetta M, Pacelli C, et al. Welfare quality ${ }^{\circledast}$ a pan-European integrated project including buffalo. Ital J Anim Sci. 2007;2(6):1360-63.

23. De Rosa G, Grasso F, Winckler C, Bilancione A, Pacelli C, Masucci F, et al. Application of the welfare quality protocol to dairy buffalo farms: prevalence and reliability of selected measures. J Dairy Sci. 2015:98: 6886-96.

24. Becker J, Steiner A, Kohler S, Koller-Bähler A, Wüthrich $M$, et al. Lameness and foot lesions in swiss dairy cows: I prevalence. Schweiz Arch Tierheilkd. 2014;156:71-8.

25. Somers J, O'Grady L. Foot lesions in lame cows on 10 dairy farms in Ireland. Irish Vet J. 2015:68:10

26. Cammarano A, Marino AL. Theorical-practical course of podology. Bubalus Bubalis. 2003;9:13-7.

27. Miekley B, Stamer E, Traulsen I, Krieter J. Implementation of multivariate cumulative sum control charts in mastitis and lameness monitoring. J Dairy Sci. 2013;96:5723-33.

28. Alsaaod M, Syring C, Dietrich J, Doherr MG, Gujan T, Steiner A. A field trial of infrared thermography as a noninvasive diagnostic tool for early detection of digital dermatitis in dairy cows. Vet J. 2003;199:281-85.

29. Nechanitzky K, Starke A, Vidondo B, Müller H, Reckardt M, Friedli K, et al. Analysis of behavioral changes in dairy cows associated with claw horn lesions. J Dairy Sci. 2016;99:2904-14.

30. Thrusfield M. Surveys. In: Thrusfield M, editor. Veterinary epidemiology. Blackwell science Ltd. London: UK; 2007. p. 228-42.

31. Italian Ministry of Health. Banca Dati Nazionale dell'Anagrafe Zootecnica. 2015. http://statistiche.izs.it/portal/page?_pageid=73,12918\&_dad=portal\&_ schema=PORTAL\&op=view_rep\&p_liv=N\&p_sigla_liv=\&p_report=plet_rep_ 11\&p_anno=2015. Accessed Mar. 2015.

32. DeFrain JM, Socha MT, Tomlinson DJ. Analysis of foot health records from 17 confinement dairies. J Dairy Sci. 2013;96:7329-39.

33. Egger-Danner C, Nielsen P, Fiedler A, Müller K, Fjeldaas T, Döpfer D, et al. ICAR Claw Health Atlas. 2015. http://www.icar.org/wp-content/uploads/ 2016/02/ICAR-Claw-Health-Atlas.pdf.

34. Weaver AD, Jean GS, Steiner A. Lameness. In: Weaver AD, Jean GS, Steiner A editors. Bovine Surgery and Lameness. 2nd ed. Oxford: Blackwell Science Ltd; 2005. p. 198-257.

35. Sprecher DJ, Hostetler DE, Kaneene JB. A lameness scoring system that uses posture and gait to predict dairy cattle reproductive performance. Theriogenology. 1997;47(6):1179-87.

36. Ezenwa VO, Jolles AE, Brien POM. A reliable body condition scoring technique for estimating condition in African buffalo. Afr J Ecol. 2009;47: 476-81.

37. Bell NJ, Huxley JN. Locomotion, lameness and mobility in dairy cows. Vet Rec. 2009;164:726-6.

38. Rutherford KMD, Langford FM, Jack MC, Sherwood L, Lawrence AB, Haskell MJ. Lameness prevalence and risk factors in organic and non-organic dairy herds in the United Kingdom. Vet J. 2009:180:95-105.

39. Huxley J, Archer S, Bell N, Burnell M, Green L, Potterton S, et al. Control of lameness. In: Green M, editor. Dairy herd health. Oxford: CABI International; 2012. p. 169-204

40. Blowey RW. Lameness in the foot. In: Andrews AH, Blowey RW, Boyd H, Eddy RG, editors. Bovine medicine disease and husbandry of cattle. 2nd ed. Oxford: Blackwell Science Ltd; 2004. p. 409-31.

41. Barker ZE, Amory JR, Wright JL, Mason SA, Blowey RW, Green LE. Risk factors for increased rates of sole ulcers, white line disease, and digital dermatitis in dairy cattle from twenty-seven farms in England and Wales. J Dairy Sci. 2009;92:1971-78.

42. Telezhenko E, Bergsten C. Influence of floor type on the locomotion of dairy cows. Appl Anim Behav Sci. 2005;93:183-97. 
43. Cook NB, Bennett TB, Nordlund KV. Effect of free stall surface on daily activity patterns in dairy cows with relevance to lameness prevalence. J Dairy Sci. 2004;87:2912-22.

44. Gomez A, Cook NB, Bernardoni ND, Rieman J, Dusick AF, Hartshorn R, et al. An experimental infection model to induce digital dermatitis infection in cattle. J Dairy Sci. 2012;95:1821-30.

45. Cheli R, Mortellaro C. Digital dermatitis in cattle. Proceedings of the 8th International Conference on Diseases of Cattle. Milan, September 9 to 13 , 1974. pp 208-213.

46. Wells SJ, Garber LP, Wagner BA. Papillomatous digital dermatitis and associated risk factors in US dairy herds. Prev Vet Med. 1999:38:11-24.

Submit your next manuscript to BioMed Central and we will help you at every step:

- We accept pre-submission inquiries

- Our selector tool helps you to find the most relevant journal

- We provide round the clock customer support

- Convenient online submission

- Thorough peer review

- Inclusion in PubMed and all major indexing services

- Maximum visibility for your research

Submit your manuscript at www.biomedcentral.com/submit
Biomed Central 